\title{
A Case Study of the Climate Factor on Thermal Comfort for Hostel Occupants in Universiti Sains Malaysia (USM), Penang, Malaysia
}

\author{
Sulaiman R S Wafi \\ School of Housing, Building and Planning \\ Universiti Sains Malaysia, Penang, Malaysia, 11800 \\ E-mail: sulimanw@hotmail.com \\ Mohd Rodzi Ismail \\ School of Housing, Building and Planning \\ Universiti Sains Malaysia, Penang, Malaysia, 11800 \\ E-mail: rodzi@usm.my \\ Egbal Mohammed Ahmed \\ School of Housing, Building and Planning \\ Universiti Sains Malaysia, Penang, Malaysia, 11800 \\ E-mail: Egbal78@yahoo.com
}

Received: February 6, 2011

Accepted: March 17, 2011

doi: $10.5539 /$ jsd.v4n5p50

\begin{abstract}
This paper aims to examine the effects of climatic factors on the indoor thermal comfort of a building occupant. The study was conducted on randomly selected hostels in Universiti Sains Malaysia (USM), Penang, involving more than nine hundred respondents. Data was collected from a questionnaire survey about the occupants' indoor comfort awareness while all contributing climatic factors were monitored and calculated daily for a week. The findings showed that there were notable differences between all parameters internally and externally. The results also found that climate affects comfort level in hostels located in a tropical climate zone. It also determined the actual thermal comfort in hostel accommodations. This study should contribute to the optimization of thermal comfort level in Malaysia.
\end{abstract}

Keywords: Thermal comfort, Building occupant, Climatic factor, Hostel

\section{Introduction}

Air temperature, globe temperature, radiant temperature, relative humidity and air velocity are factors affecting the thermal comfort performance of any indoor environment. Hostel occupants' satisfaction of their indoor comfort level depends a lot on the building's design and infrastructure. In recent years, global attention on the issue of a building occupant's thermal comfort has generated many thermal studies on the different types of buildings. These studies took place in many countries with different climates, heating and ventilation systems such as the studies by Lazzerini et al., (1991); Warden et al., (2004); Howell et al., (2004), Manz et al., (2005); Kunzel et al., (2005).

There have been many studies on different ways of evaluating thermal comfort to find out if a thermal environment is suitable for comfortable living. Certain design criteria for thermal comfort have affected designs of buildings and their control system according to Brager \& Dear (2000); ASHRAE (2004). ASHRAE 55 (ASHRAE 2004) and ISO 7730 (ISO 1994) can identify physical measurements and verify thermal variables within comfort range such as that in indoor thermal parameters.

According to Lee \& Chang, (2000) many people in general spend more than $90 \%$ of their time indoors; therefore, healthy indoor air velocity is extremely beneficial to their well being. The elimination of many health problems is possible through thorough investigation of air velocity in students' hostels. According to Cheng et al., (2008), when using the fan, the acceptable range obtained from direct and indirect investigations are 28.2 and $27.2^{\circ} \mathrm{C}$, 
respectively. Convective heat transfer that creates more uniform temperature distribution throughout the room comes from strong circulations forced by the fan (Ho et al., 2009).

According to Fanger (1982), thermal comfort refers to metabolism levels that can be assessed by variables that include activities, clothing resistance, air temperature, relative humidity, air velocity, and mean radiant temperature. Two groups of personal physiological variables of metabolism are 1) result of activities and the thermal resistance of clothing; and 2) climate variables that include air temperature, air velocity, relative humidity and radiant temperature (Humphreys \& Nicol, 2002).

Body proportions, the female mensuration cycle, age, sex, food, international air movements and irregular indoor thermal comfort expectation are some of the physical-physiological variables that can help to define thermal comfort expectation (Auliciems, 1989; Wong et al., 2002; Brager \& Dear, 1998).

Penang Island is located in Malaysia at latitude $5^{\circ} 25^{\prime} \mathrm{N}$, and longitude $100^{\circ} 19^{\prime} \mathrm{E}$. According to the Malaysian Meteorological Service (MMS), the temperature range for Penang is between $27{ }^{\circ} \mathrm{C}-33{ }^{\circ} \mathrm{C}$ during the day and $22{ }^{\circ} \mathrm{C}-24{ }^{\circ} \mathrm{C}$ during the night. The relative humidity level is between $70 \%-90 \%$.

Penang enjoys a tropical rainforest climate which is warm and sunny during the dry monsoon. Heavy rainfall occurs during the south-west monsoon from April to September. The sea around Penang Island dictates its climate. Dust particles from transient forest fires in Sumatra affect Penang when the wind carry them over [source: Malaysian Metrological Service (MMS), 2009].

\section{Methodology}

The study conducted field experiments from 16th February to 2nd July 2009. Daily measurements were taken from 8 am till 12 midnight for a period of one week. Hourly readings were taken for air temperature, relative humidity, wind velocity and globe temperature. Each hostel measurement lasted a week and each sample room was measured on different floors with the purpose of identifying the environmental effect on the hostel occupants. The ruling indoor environmental parameters of the hostels including air temperature, relative humidity, wind velocity and globe temperature were measured internally and externally at the same time.

The SEKONIC ST-50 HYGRO - THERMOGRAPH instrument, which is capable of measuring air temperatures and relative humidity, was used to calculate the air temperatures. A $38 \mathrm{~mm}$ diameter globe thermometer instrument was used to determine radiant temperatures, which were computed from the measured globe temperature. A battery operated TESTO 415 instrument which has a thermal velocity probe measured external and internal wind.

The USM hostels involved in this study were International House (IH), Dessasiswa Bakti Permai (D.BP), Dessasiswa Restu (D.R), Dessasiswa Indah Kembara (D.IK), Dessasiswa Saujana (D.S), Dessasiswa Tekun (D.T), Dessasiswa Cahaya Gemilang (D.CG), Dessasiswa Aman Damai (D.AD), and Dessasiswa Fajar Harapan (D.FH), . Linear Regression and Logistic Regression was used as the methodology for the evaluation of all hostels in this study.

\section{Result and Analysis of Data Collection}

\subsection{PPD and PMV for Student in Each Hostel}

Table 1 shows the PPD (predicted percentage of dissatisfied) students and the PMV (predicted mean vote) in each of the nine hostels surveyed and the relationships between PPD and PMV. Table 1 shows the predicted percentage of dissatisfied (PPD) students and the predicted mean vote (PMV) in each of the nine hostels surveyed. Indoor thermal environment is crucial as it affects the health and productivity of building occupants, (Shiming et al. 2009). When the PMV was 1.6, the PPD was 56.3\% in D.I.K. When the PMV was 2.3, the PPD was $88.3 \%$ in D.C.G. The research showed that when the PMV increase, the PPD increases too.

\subsection{Regression Line (Summary of the Analysis)}

Table 2 presents the data from the Linear Regression equations which include Regression Coefficient, Intercept, R2, Correlation, T Comfort, and Significance for each hostel.

Findings in this study show that the regression coefficient (slope) is $12.73 /{ }^{\circ} \mathrm{C}$ with an intercept of -0.45 and a low R2 of 0.33 for a full sample. Table 2 illustrates the other samples. Occupants in real buildings compensate for temporary changes by changing their clothing, and this contributes to the lower slope values in the field studies. The movement of the airflow and ventilation in the building affects different individuals' temperature comfort. The author's findings imply that the Malaysian subjects willingly adapt to a range of indoor thermal conditions through modification of clothing. 


\subsection{Natural Temperature for Various Groups of Subjects}

Table 3: This illustration shows simple linear regression in relation to the air temperature scale as a dependent variable.

Table 3 illustrates the thermal comfort for all the occupants in the hostels. The thermal comfort was found to be higher for male than female, at $28.8^{\circ} \mathrm{C}$ and $28.3^{\circ} \mathrm{C}$, respectively. The physical difference and Clo value of the male and female physique affect the difference of comfort in both sexes, as the male wears less clothing than the female while indoors. Therefore, it is safe to conclude that at the 5\% level of importance, male and female were significantly, and differently affected by the air temperature scale, $\mathrm{p}<0.05$.

The Clo value distribution for male and female occupants ranges from 0.05 to 0.93 . The resulting analysis showed that male occupants have a larger range of Clo values than the female occupants. The Clo values for the male range from between 0.05 tp 0.93 while values for the female range from 0.12 to 0.87 . The results also showed that the Clo values for the largest number (for Clo values) fall into 0.18 Clo for the female group and 0.17 Clo for the male group.

\section{Hostels' Measurements}

Legend: Temperature $=\mathrm{T}^{\circ} \mathrm{C}$, Relative humidity $=\mathrm{RH} \%$, Air Velocity $=\mathrm{V} \mathrm{m} / \mathrm{s}$,

Globe temperature $=\mathrm{GT}^{\circ} \mathrm{C}$

Result and Discussion of Case Studies

The study measured the hostels, firstly, to present the various climatic factors like temperature, humidity, air velocity and globe temperature and secondly to differentiate between the internal and external climatic factors including the existing situation from the comfort zone. Here, we can see the final set of observations and discussions for air temperature, relative humidity, air velocity and globe temperature for indoor and outdoor from 8 am to 12 midnight for one week for each respective hostel.

\subsection{Air Temperature}

The speed of molecules moving within a material defines a measurement of temperature. Chemical reactions are more likely to happen when the molecules move faster and collide with each other frequently. Heat accelerates the chemical reactions when molecules move rapidly at higher temperatures, and this leads to quicker deterioration. The rate of many chemical reactions doubles with an increase in temperature; therefore, a lower temperature means a slower rate of deterioration.

The coolest time of the day, is observed to be prior to 10:00 am, and after 6:00 pm when the temperature falls. The hottest time of the day is when temperatures climb. It is also noted that the rate of temperature peaking is decidedly much faster than that of the rate of declining. The highest average outdoor temperature during the nine weeks of the study was $38{ }^{\circ} \mathrm{C}$ at $03: 00 \mathrm{pm}$ while the minimum outdoor temperature during the same period was $27.6{ }^{\circ} \mathrm{C}$ at $12: 00$ am showing a difference of $10.4{ }^{\circ} \mathrm{C}$. This meant that all this time, the average outdoor temperature during the daytime was outside the comfort zone (ASHRAE standard).

The highest indoor temperature noted for all sample hostels was $33.6^{\circ} \mathrm{C}$ in the early afternoon when the outdoor temperature was $36.5^{\circ} \mathrm{C}$. The lowest indoor temperature at $11 \mathrm{pm}$ in the night was $27.5^{\circ} \mathrm{C}$. The difference between the maximum outdoor and indoor temperature was $4.4^{\circ} \mathrm{C}$, which is to say, that all the time the indoor temperature was outside the comfort zone. However, in the mornings and evenings, the air temperature was remarkably close to the comfort zone (ASHRAE standard).

Figure 1 shows the daily behaviour of internal and external air temperature at all hostels from 8:00 am to 12:00 $\mathrm{pm}$ measured in a period of one week.

\subsection{Relative Humidity}

Measurements for relative humidity include the ratio of the actual water vapour content of the air at the given temperature; the mixing ratio / mass of water vapour per unit of dry air; water vapour per unit volume of natural air; relative and specific humidity. It was noticed that the outdoor relative humidity was lower than the indoor relative humidity during the measurements which lasted one week.

Figure 2 and 3 show that the overall variation was minimal, ranging from $50.5 \%$ to $79.7 \%$, during the nine weeks of study. The highest humidity was recorded before 10:00 am and after 5:00 pm. There was more room for absorption of moisture from its immediate surroundings when the air got warmer and the air mass expands.

Figure 2 shows the relations between indoor relative humidity and air temperature (from 8:00 am to 12:00 am) 
Figure 3 shows the relations between outdoor relative humidity and air temperature (from 8:00 am to 12:00 am)

Relative humidity refers to the quantity of water vapour in the air at a certain temperature in relation to the highest amount that the air could hold at that temperature.

If we refer to Figure 3, it can be seen that the outdoor relative humidity was always less than the indoor relative humidity due to the indoor temperature being lower than the outdoor temperature.

The study found that the percentage of relative humidity on the higher floor was better than that on the lower floors, especially from the fifth to the tenth floor, however, this percentage was still out of the comfort zone (ASHRAE standard). More than $80 \%$ of relative humidity was recorded in the time that the air temperature was declining and air velocity maintained from between 0.01 to $0.9 \mathrm{~m} / \mathrm{s}$ but when the air temperature started to climb, the relative humidity descended.

Figure 4 shows the behaviour of indoor and outdoor relative humidity at all hostels recorded in one week from 8:00 am to $12: 00 \mathrm{am}$.

\subsection{Air Movement}

From a week's measurements, it was found that the air speed was better on the higher floors compared to the lower ones. Higher outdoor wind speed commences from 11 am till $6 \mathrm{pm}$ ranging in higher velocity than $0.9 \mathrm{~m} / \mathrm{s}$ outdoors, $0.5 \mathrm{~m} / \mathrm{s}$ with the door opened, and $0.1 \mathrm{~m} / \mathrm{s}$ with the door closed. For approximately 7 hours per day during this period, air velocities were above $1 \mathrm{~m} / \mathrm{s}$ outdoors and occasionally more than $2.3 \mathrm{~m} / \mathrm{s}$.

Indoor air movement with the door opened was highest at $0.8 \mathrm{~m} / \mathrm{s}$ while the lowest value was $0.3 \mathrm{~m} / \mathrm{s}$ with the difference at $0.5 \mathrm{~m} / \mathrm{s}$. The average highest value for indoor air movement with the door closed was $0.3 \mathrm{~m} / \mathrm{s}$ and the lowest value at $0.1 \mathrm{~m} / \mathrm{s}$ showing a difference of $0.2 \mathrm{~m} / \mathrm{s}$. Measurements confirmed that the air speed with the door opened was a lot better than that with the door closed.

Figure 5 shows the behaviour of indoor and outdoor air velocity at all hostels recorded in one week from 8:00 am to $12: 00 \mathrm{am}$.

\subsection{Globe Temperature}

During this period of study, the average highest value for outdoor globe temperature was recorded at $46.7^{\circ} \mathrm{C}$ and the lowest at $27.4{ }^{\circ} \mathrm{C}$ showing a difference of $19.3^{\circ} \mathrm{C}$. The average highest value for indoor globe temperature was $34.4^{\circ} \mathrm{C}$ and the lowest at $27.4^{\circ} \mathrm{C}$, showing a difference of $7{ }^{\circ} \mathrm{C}$.

Figure 6 shows the behaviour of indoor and outdoor globe temperature at all hostels recorded in one week from 8:00 am to $12: 00 \mathrm{am}$.

The hottest time of the day was from 11:00 am to 4:00 pm wherein the globe temperature rose rapidly but descended from 4:00 $\mathrm{pm}$. The rate of peaking was faster than the rate of declining.

\subsection{Radiant Temperature}

The Mean Radiant Temperature (Tr) is an idea coming from the reality that the net exchange of radiant energy between two objects is almost equal to their temperature difference, multiplied by their capability to give out, and absorb heat (emissivity).

Comfort is not achieved if the $\mathrm{Tg}$ is above $28{ }^{\circ} \mathrm{C}$ or below $16{ }^{\circ} \mathrm{C}$ (Evans, 1980). Method of measuring mean radiant temperature is to use, $\mathrm{Tg}, \mathrm{Ta}$ and $\mathrm{V}$.

Mean radiant temperature (Tr) can be calculated using the following equation (ASHRAE Handbook, 1993):

$$
T_{r}=\left[\left(T_{g}+273\right)^{4}+\frac{1.10 \times 10^{8} V^{0.6}}{\in D^{0.4}}\left(T_{g}-T_{a}\right)\right]^{1 / 4}-273
$$

Where,

$$
\begin{aligned}
\mathrm{Tr} & =\text { mean radiant temperature, }{ }^{\circ} \mathrm{C} \\
\mathrm{V} & =\text { air velocity, } \mathrm{ms}^{-1} \\
\mathrm{D} & =\text { Globe diameter, } \mathrm{m} \\
\epsilon & =\text { Emissivity }(0.95 \text { for black globe })
\end{aligned}
$$


The highest average outdoor radiant temperature was $65.4^{\circ} \mathrm{C}$, and the lowest was $27^{\circ} \mathrm{C}$, showing a difference of $38.4^{\circ} \mathrm{C}$. The highest average indoor radiant temperature was $39.1^{\circ} \mathrm{C}$, and the lowest was $27.2^{\circ} \mathrm{C}$, showing a difference of $11.9^{\circ} \mathrm{C}$.

Figure 7 shows the behaviour of indoor and outdoor radiant temperature at all hostels recorded in one week from 8:00 am to $12: 00 \mathrm{am}$.

\subsection{Summary of the Study of Nine Hostels}

The study was carried out at nine randomly selected hostels in USM Penang. Outdoor and indoor readings for climatic data were taken. Indoor measurements were obtained from various rooms and floors. Only some rooms in International House have air-conditioning whereas the rest of the hostel rooms were equipped with ceiling fans. Unsatisfactory readings were obtained with the door closed. However, the room readings improved when the door was opened as this allowed air flow into the room.

This meant that natural ventilation can help to reduce unfavorable indoor air temperature and relative humidity.

Hostel building designers can apply the idea of creating an additional window on the opposite side of the room to facilitate better air flow, as is shown in the nine experiments discussed earlier.

\section{Multiple Regressions, Logistic Regression}

Binary Multiple Logistic Regression

Table 4 presents summary of Crude Multiple Logistic Regression.

a. Crude Multiple Logistic Regression on gender as a dependent variable and segregated by ethnicity. The assessed goodness of fit using Hosmer-Lemeshow test p-value (All = 0.375; Malay =0.039; Chinese = 0.015 ; Indian $=0.188$; others $=0.326$ ).

Logit transformation equation for each model:-

\section{a. All Ethnicity;}

$\log _{10}(p / 1-p)=-13.878+\left[0.187 *_{\text {AIRTEMPERATURE }}\right]+\left[0.073 *_{\text {RELATIVEHUMIDITY }}\right]+\left[0.110 *_{\text {AIRVELOCITY }}\right]+$ $\left[0.125 *{ }_{\text {GLOBETEMPERATURE }}\right]$

b. Malay

$\log _{10}(p / 1-p)=-8.534+\left[-0.074 *_{\text {AIRTEMPERATURE }}\right]+\left[0.027 *_{\text {RELATIVEHUMIDITY }}\right]+\left[0.229{ }^{*}{ }_{\text {AIRVELOCITY }}\right]+$ $\left[0.326 *{ }_{\text {GLOBETEMPERATURE }}\right]$

\section{c. Chinese}

$\log _{10}(p / 1-p)=-20.005+\left[0.323 *_{\text {AIRTEMPERATURE }}\right]+\left[0.129 *_{\text {RELATIVEHUMIDITY }}\right]+\left[-0.338^{*}{ }_{\text {AIRVELOCITY }}\right]+$ $\left[0.049 *{ }_{\text {GLOBETEMPERATURE }}\right]$

\section{d. Indian}

$\log _{10}(p / 1-p)=-31.890+\left[0.38 *^{*}{ }_{\text {AIRTEMPERATURE }}\right]+\left[0.096^{*}{ }_{\text {RELATIVEHUMIDITY }}\right]+\left[-2.272 *_{\text {AIRVELOCITY }}\right]+$ $\left[0.411 *{ }_{\text {GLOBETEMPERATURE }}\right]$

e. Others

$\log _{10}(\mathrm{p} / 1-\mathrm{p})=-49.332+\left[1.832 *_{\text {AIRTEMPERATURE }}\right]+\left[0.239 *_{\text {RELATIVEHUMIDITY }}\right]+\left[-0.313 *_{\text {AIRVELOCITY }}\right]+$ [0.730* ${ }_{\text {GLOBETEMPERATURE }]}$

\section{Interpretation:}

\subsection{Model for All Ethnicity:-}

A $1{ }^{\circ} \mathrm{C}$ increase in air and globe temperature would affect the comfort levels of female students by 1.206 and 1.133 times respectively compared to male students with other variables held constant. If there is a $1 \%$ increase in relative humidity the female students will be affected by 1.076 times more than the male students.

All ethnicity comprise 679 female students and 250 male students. The overall model is valid for prediction (Omnibus test $\mathrm{p}$-value $<0.001$ ), and the Hosmer-Lemeshow goodness of fit test $\mathrm{p}$-value is 0.375 which indicated that the model is fit.

\subsection{Model for Malay Ethnicity:-}

A $1{ }^{\circ} \mathrm{C}$ increase in air and globe temperature for the Malay ethnicity would affect the comfort levels of female students by 0.928 and 1.385 times respectively compared to male students with other variables held constant. If there is a $1 \%$ or $1 \mathrm{~m} / \mathrm{s}$ increase in relative humidity and air velocity the female students will be affected by 1.027 and 1.257 times more than the male students. 
The total respondents from the Malay ethnicity comprise 477 female students and 133 male students. The overall model for the Malay ethnicity is valid for prediction (Omnibus test p-value $=0.004$ ); unfortunately the Hosmer-Lemeshow goodness of fit test p-value is 0.039 which indicated that this model is not fit.

\subsection{Model for Chinese Ethnicity:-}

A $1{ }^{\circ} \mathrm{C}$ increase in air and globe temperature for the Chinese ethnicity would affect the comfort levels of female students by 1.381 and 1.050 times respectively compared to male students with other variables held constant. If there is a $1 \%$ or $1 \mathrm{~m} / \mathrm{s}$ increase in relative humidity and air velocity the female students will be affected by 1.137 and 0.714 times more than the male students.

The total respondents from the Chinese ethnicity comprise 126 female students and 84 male students. The overall model for the Chinese ethnicity is valid for prediction (Omnibus test $\mathrm{p}$-value $=0.008$ ); unfortunately the Hosmer-Lemeshow goodness of fit test p-value is 0.015 which indicated that this model is not fit.

\subsection{Model for Indian ethnicity:-}

A $1{ }^{\circ} \mathrm{C}$ increase in air and globe temperature for the Indian ethnicity would affect the comfort levels of female students by 1.469 and 1.508 times respectively compared to male students with other variables held constant. If there is a $1 \%$ or $1 \mathrm{~m} / \mathrm{s}$ increase in relative humidity and air velocity the female students will be affected by 1.101 and 9.694 times more than the male students.

The total respondents from the Indian ethnicity comprise 28 female students and 13 male students. The overall model for the Indian ethnicity is valid for prediction (Omnibus test p-value $=0.153$ ); the Hosmer-Lemeshow goodness of fit test p-value is 0.188 which indicated that this model is fit. This is because the sample size of the Indian ethnicity is very small.

\subsection{Model for Other Ethnicity:-}

A $1{ }^{\circ} \mathrm{C}$ increase in air and globe temperature for the Indian ethnicity would affect the comfort levels of female students by 6.245 and 0.482 times respectively compared to male students with other variables held constant. If there is a $1 \%$ or $1 \mathrm{~m} / \mathrm{s}$ increase in relative humidity and air velocity the female students will be affected by 1.270 and 0.731 times more than the male students.

The total respondents from the other ethnicity comprise 44 female students and 19 male students. The overall model for other ethnicity is valid for prediction (Omnibus test p-value $=0.002$ ); the Hosmer-Lemeshow goodness of fit test p-value is 0.347 which indicated that this model is fit.

\section{Interpretation:-}

\subsection{Air Temperature}

The F-value in the ANOVA table significantly indicates the air temperature scale for male at $37.4 \%$ of the variance (R square) and for female at $31.4 \%$. When examined, the t-value indicated that variables for male and female contribute to the air temperature scale.

\section{Conclusion}

The purpose of this study was to investigate whether the hostel occupants were satisfied with their accommodation and to determine if there were any imbalances. Our findings showed that all hostel rooms have problems with temperature, humidity and especially air flow as their rooms do not have windows on the opposite wall which severely limit the airflow circulation

It was observed that the comfort temperature for the Malaysian student is $28.5^{\circ} \mathrm{C}$. Regression of mean thermal sensation scale responses confirmed the sensitivity of Malaysian students to their thermal environment. It also suggested that respondents in Malaysia were readily adapting themselves to various indoor conditions through clothing modification, using the fan and opening the door.

There was not much differences found in the responses from male and female respondents about their indoor comfort. The comfort temperature for male and female was found to be $28.8^{\circ} \mathrm{C}$ and $28.35^{\circ} \mathrm{C}$, respectively

\section{References}

ASHRAE. (2001). ASHRAE Fundamentals Handbook (SI). Atlanta: American Society of Heating Refrigerating and Air-conditioning Engineers Inc.

ASHRAE. (2004). ANSI/ASHRAE Standard 55-2004, Thermal Environmental Conditions for Human Occupancy. Atlanta: American Society of Heating Refrigerating and Air-conditioning Engineers Inc. 
Auliciems, A. (1989). Thermal comfort, dalam Nancy C. Ruck, 1989, Building Design and Human Performance, Van Nostrand, New York.

Brager, G.S. \& de Dear. (2000). A Standard for Natural Ventilation. ASHARE Journal (42)10: 21-29.

Brager, G.S. \& de Dear. (1998). Thermal Adaptation in the Built Environment, A Literature Review. Journal Energy and Buildings (27): 84-95.

Cheng, Ming-Jen., Hwang,Ruey-Lung, \& Lin, Tzu-Ping. (2008). Field Experiments on Thermal Comfort Requirements for Campus Dormitories in Taiwan. Published by SAGE, Indoor built environ (17)3: 191-202. doi:10.1177/1420326X08090571, http://dx.doi.org/10.1177/1420326X08090571

Ho, H. Son., Rosario, Luis., \& Muhammad M. Rahman. (2009). Thermal Comfort Enhancement by Using A Ceiling Fan. Applied Thermal Engineering (29)8-9) pp. 1648-1656.

Howell, R. H., \& Land, D. W. (2004). Air-cooled HVAC retrofit: Safe bet for vegas schools: ASHRAE American Society of Heating Refrigerating and Air-conditioning Engineers Journal,46:28-34.

Humphreys \& Nicol. (2002). The Validity of ISO-PMV for Predicting Comfort Votes in Every-Day Thermal Environments, Journal Energy and Building, (34): 667-684.

ISO. (1994). International Standard 7730, Moderate Thermal Environment: Determination of PMV and PPD Indices and Specification of Conditions for Thermal Environment. International Organization for Standardization, Geneva.

Kunzel, H., Holm, A., Zirkelbach, D., \& Karagiozis, A. (2005). Simulation of indoor temperature and humidity conditions including hygrothermal interactions with the building envelope, Sol Energy, 78:554-561. doi:10.1016/j.solener.2004.03.002, http://dx.doi.org/10.1016/j.solener.2004.03.002

Fanger. (1982). Thermal Comfort Analysis and Applications in Environmental Engineering, Rebert E Krienger Publishing Company, Malabar, Florida.

Lazzerini, R., Curtis, D., Bowen, R., Patel, M., Ruscisa, G., Lazzerini, P., Renzio, M., Zabot,S., Guarino, D., \& Cellie, A. (1991). ANNEX XV - Energy Efficiency in Schools. Part One. Paris, IEA - International Energy Agency, Corso Brescia 62 - 10152 Torino.

Lee, S.C., \& Chang, M. (2000). Indoor and Outdoor Air Quality Investigation at Schools in Hong Kong. PERGAMON Journal, Chemosphere 41:09-113.

Malaysian Metrological Service, MMS, (2009). Climate of Penang.

Manz, H., \& Frank, T. (2005). Thermal simulation of buildings with double-skin fac,ades: Energy Build, 37:1114-1121. doi:10.1016/j.enbuild.2005.06.014, http://dx.doi.org/10.1016/j.enbuild.2005.06.014

Shiming, Deng., Zheng, Li., \& Minglu, Qu. (2009). Indoor Thermal Comfort Characteristics Under the Control of A Direct Expansion Air Conditioning Unit Having A Variable-Speed Compressor and A Supply air fan. Applied Thermal Engineering (29)11-12: 2187-2193. doi:10.1016/j.applthermaleng.2008.10.011, http://dx.doi.org/10.1016/j.applthermaleng.2008.10.011

Warden, D. (2004). Dual fan, dual duct goes to school. ASHRAE American Society of Heating Refrigerating and Air-conditioning Engineers Journal, 46:18-27.

Wong, H. N., Feriadi, H., Lim, P. Y., Tham, K. W., Sekhar, C., \& Cheong, K. W. (2002). Thermal Comfort Evaluation of Naturally Ventilated Public Housing in Singapore, Journal building and environment, 37: 1267-1277. 
Table 1. Summary of PPD and PMV for Students in Each hostel.

\begin{tabular}{|l|l|l|l|l|l|l|l|l|l|}
\hline & DR & DT & DS & DIK & DAD & DBP & DFH & IH & DCG \\
\hline PPD & $67 \%$ & $72.1 \%$ & $81.1 \%$ & $56.3 \%$ & $61.8 \%$ & $67 \%$ & $88.3 \%$ & $84.9 \%$ & $88.3 \%$ \\
\hline PMV & 1.8 & 1.9 & 2.1 & 1.6 & 1.7 & 1.8 & 2.3 & 2.2 & 2.3 \\
\hline
\end{tabular}

Table 2. Summary of Linear Regression for All Hostels

\begin{tabular}{|l|l|l|l|l|l|l|}
\hline Subjects & Regression Coefficient & Intercept & $\mathbf{R}^{\mathbf{2}}$ & $\begin{array}{l}\text { Correlation } \\
(\mathbf{R})\end{array}$ & $\begin{array}{l}\mathbf{T}_{\mathbf{c}} \\
\left({ }^{\circ} \mathbf{C}\right)\end{array}$ & Significance \\
\hline All Hostels & 12.73 & -0.45 & 0.33 & 0.577 & 28.2 & 0.000 \\
\hline D. T & 14.22 & -0.50 & 0.40 & 0.631 & 28.5 & 0.000 \\
\hline D.R & 10.58 & -0.38 & 0.59 & 0.771 & 27.9 & 0.000 \\
\hline D.S & 16.37 & -0.57 & 0.57 & 0.753 & 28.8 & 0.000 \\
\hline D.I K & 18.94 & -0.65 & 0.45 & 0.668 & 29.1 & 0.000 \\
\hline D.AD & 18.40 & -0.65 & 0.09 & 0.302 & 28.5 & 0.001 \\
\hline D.BP & 10.74 & -0.38 & 0.26 & 0.507 & 28.3 & 0.000 \\
\hline D.C G & 18.38 & -0.62 & 0.56 & 0.746 & 29.7 & 0.000 \\
\hline D.F H & 14.86 & -0.50 & 0.20 & 0.450 & 29.5 & 0.002 \\
\hline I. H & 18.50 & -0.63 & 0.33 & 0.571 & 29.3 & 0.001 \\
\hline
\end{tabular}

Table 3. Simple Linear Regression on Air Temperature Scale as a Dependent Variable

\begin{tabular}{|l|l|l|l|l|}
\hline Variable All Air Temperature & $\begin{array}{l}\text { Regression } \\
\text { Coefficient }\end{array}$ & Intercept & R square & $\mathbf{T}_{\mathbf{c}}$ \\
\hline Male & 12.73 & -0.442 & 0.374 & $28.8^{\circ} \mathrm{C}$ \\
\hline Female & 12.815 & -0.452 & 0.314 & $28.3^{\circ} \mathrm{C}$ \\
\hline
\end{tabular}

Binary Multiple Logistic Regression 
Table 4. Summary of Crude Multiple Logistic Regression

\begin{tabular}{|c|c|c|c|c|c|c|}
\hline Variable & $\begin{array}{l}\text { Male } \\
\text { N (\%) }\end{array}$ & $\begin{array}{l}\text { Female } \\
\text { N (\%) }\end{array}$ & $\mathbf{b}^{\mathbf{a}}$ & Adjusted OR (95\% CI) & $\begin{array}{l}\text { Wald } \\
\text { Statistic }\end{array}$ & p-value \\
\hline All & \multirow{5}{*}{$\begin{array}{l}250 \\
(100 \%)\end{array}$} & \multirow{5}{*}{$\begin{array}{l}679 \\
(100 \%)\end{array}$} & & & & \\
\hline Air Temperature & & & 0.187 & $1.206(0.888,1.639)$ & 1.434 & 0.231 \\
\hline $\begin{array}{l}\text { Relative } \\
\text { Humidity }\end{array}$ & & & 0.073 & $1.076(1.035,1.118)$ & 13.871 & $<0.001$ \\
\hline Air Velocity & & & 0.110 & $1.117(0.700,1.782)$ & 0.214 & 0.643 \\
\hline $\begin{array}{c}\text { Globe } \\
\text { Temperature }\end{array}$ & & & 0.125 & $1.133(0.869,1.478)$ & 0.850 & 0.357 \\
\hline Constant & \multicolumn{6}{|l|}{-13.878} \\
\hline Malay & \multirow{5}{*}{$\begin{array}{l}133 \\
(53.2 \%)\end{array}$} & \multirow{5}{*}{$\begin{array}{l}477 \\
(70.3 \%)\end{array}$} & & & & \\
\hline Air Temperature & & & -0.074 & $0.928(0.591,1.459)$ & 0.104 & 0.747 \\
\hline $\begin{array}{c}\text { Relative } \\
\text { Humidity }\end{array}$ & & & 0.027 & $1.027(0.974,1.083)$ & 0.995 & 0.318 \\
\hline Air Velocity & & & 0.229 & $1.257(0.693,2.279)$ & 0.566 & 0.452 \\
\hline $\begin{array}{c}\text { Globe } \\
\text { Temperature }\end{array}$ & & & 0.326 & $1.385(0.929,2.064)$ & 2.554 & 0.110 \\
\hline Constant & \multicolumn{6}{|l|}{-8.534} \\
\hline Chinese & \multirow{5}{*}{$\begin{array}{l}84 \\
(33.6 \%)\end{array}$} & \multirow{5}{*}{$\begin{array}{l}126 \\
(18.6 \%)\end{array}$} & & & & \\
\hline Air Temperature & & & 0.323 & $1.381(0.788,2.419)$ & 1.272 & 0.259 \\
\hline $\begin{array}{l}\text { Relative } \\
\text { Humidity }\end{array}$ & & & 0.129 & $1.137(1.056,1.225)$ & 11.607 & 0.001 \\
\hline Air Velocity & & & -0.338 & $0.714(0.268,1.898)$ & 0.457 & 0.499 \\
\hline $\begin{array}{c}\text { Globe } \\
\text { Temperature }\end{array}$ & & & 0.049 & $1.050(0.646,1.707)$ & 0.039 & 0.844 \\
\hline Constant & \multicolumn{6}{|l|}{-20.005} \\
\hline Indian & \multirow{5}{*}{$13(5.2 \%)$} & \multirow{5}{*}{$\begin{array}{l}28 \\
(4.1 \%)\end{array}$} & & & & \\
\hline Air Temperature & & & 0.385 & $1.469(0.243,8.880)$ & 0.176 & 0.675 \\
\hline $\begin{array}{l}\text { Relative } \\
\text { Humidity }\end{array}$ & & & 0.096 & $1.101(0.912,1.330)$ & 1.007 & 0.316 \\
\hline Air Velocity & & & 2.272 & $9.694(0.533,176.218)$ & 2.357 & 0.125 \\
\hline $\begin{array}{c}\text { Globe } \\
\text { Temperature }\end{array}$ & & & 0.411 & $1.508(0.272,8.354)$ & 0.221 & 0.638 \\
\hline Constant & \multicolumn{6}{|l|}{-31.890} \\
\hline Others & \multirow{5}{*}{$19(7.6 \%)$} & \multirow{5}{*}{$\begin{array}{l}44 \\
(6.5 \%)\end{array}$} & & & & \\
\hline $\begin{array}{c}\text { Air } \\
\text { Temperature }\end{array}$ & & & 1.832 & $6.245(1.397,27.919)$ & 5.747 & 0.017 \\
\hline $\begin{array}{l}\text { Relative } \\
\text { Humidity }\end{array}$ & & & 0.239 & $1.270(1.065,1.514)$ & 7.114 & 0.008 \\
\hline Air Velocity & & & -0.313 & $0.731(0.076,7.031)$ & 0.074 & 0.786 \\
\hline $\begin{array}{c}\text { Globe } \\
\text { Temperature }\end{array}$ & & & -0.730 & $0.482(0.145,1.604)$ & 1.416 & 0.234 \\
\hline
\end{tabular}

Crude Multiple Logistic Regression on gender as a dependent variable and segregated by ethnicity. The assessed goodness of fit using Hosmer-Lemeshow test $\mathrm{p}$-value (All $=0.375$; Malay $=0.039$; Chinese $=0.015$; Indian $=$ 0.188 ; others $=0.326$ ) 


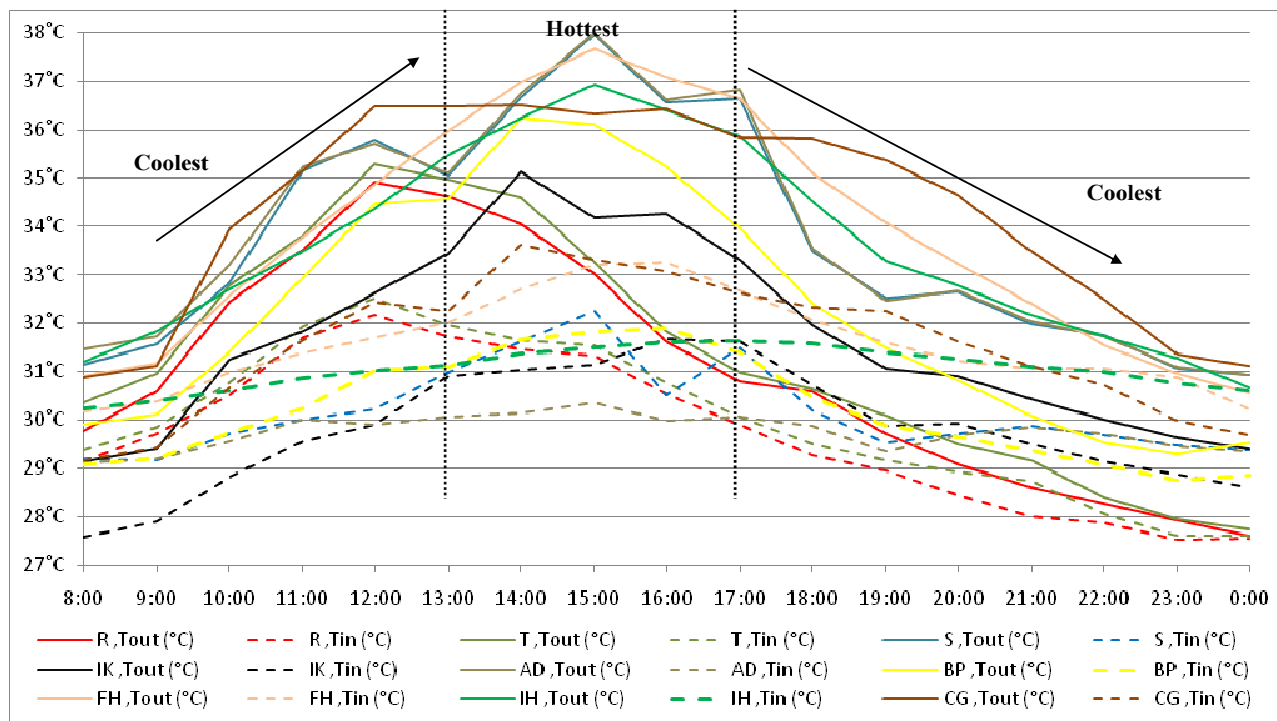

Figure 1. The behavior of inside and outside air temperature at all hostels. For one week from 8:00 am to 12:00 am

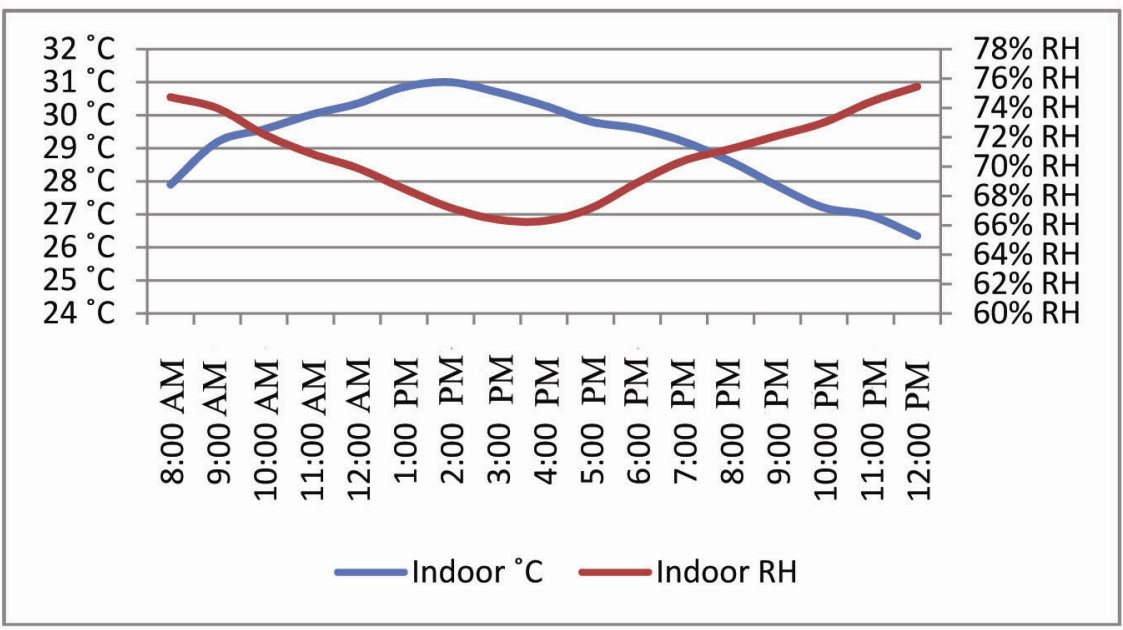

Figure 2. Relations between indoor relative humidity and air temperature(8:00 am to 12:00 am)

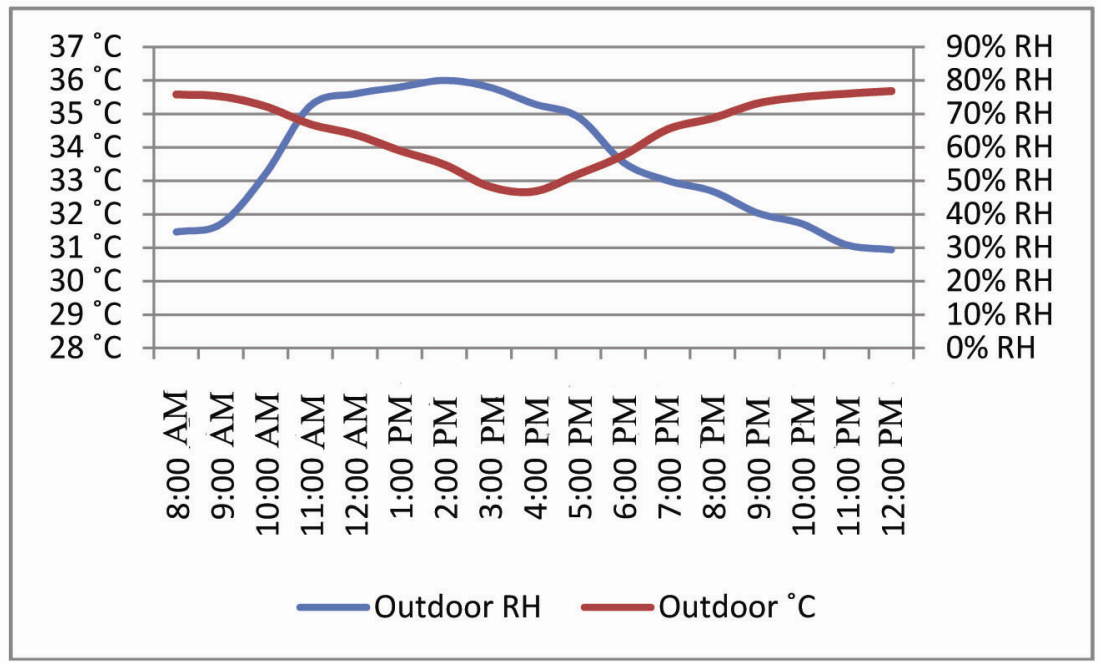

Figure 3. Relations between outdoor relative humidity and air temperature (8:00 am to 12:00 am) 


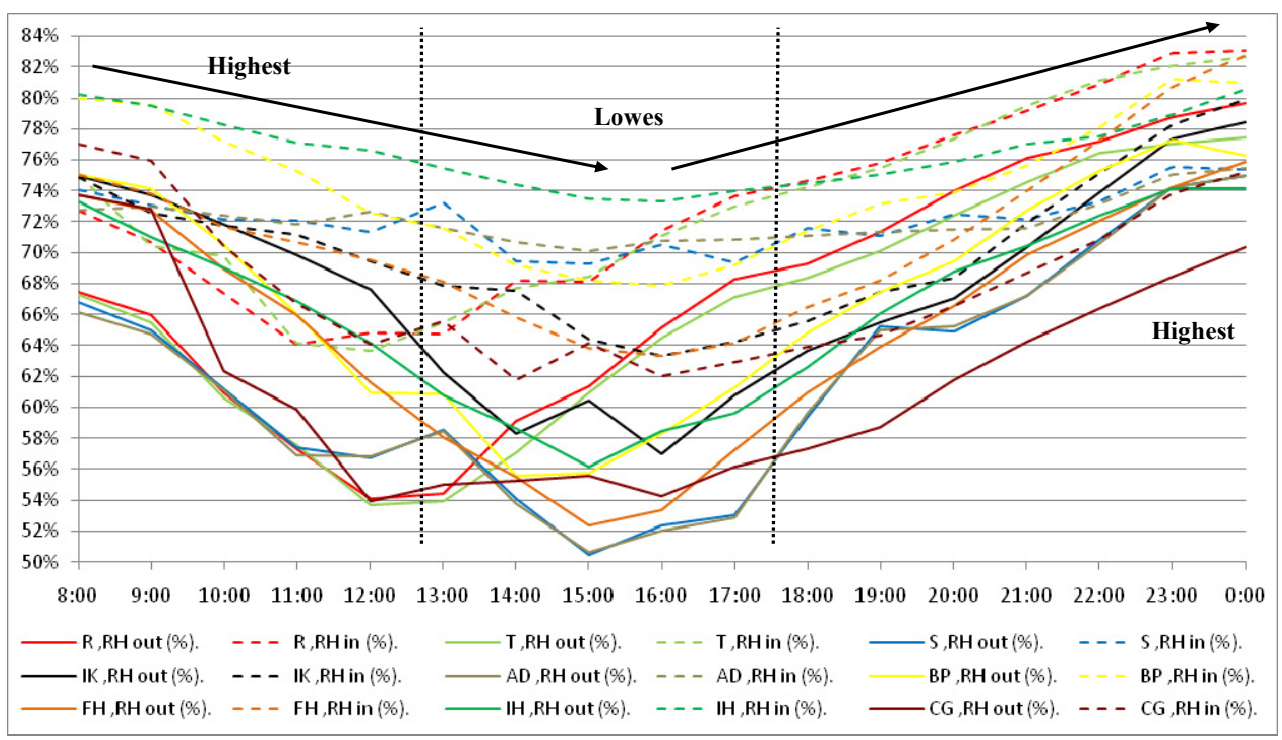

Figure 4. The behavior of indoor and outdoor relative humidity at all hostels recorded in one week from 8:00 am to $12: 00 \mathrm{am}$

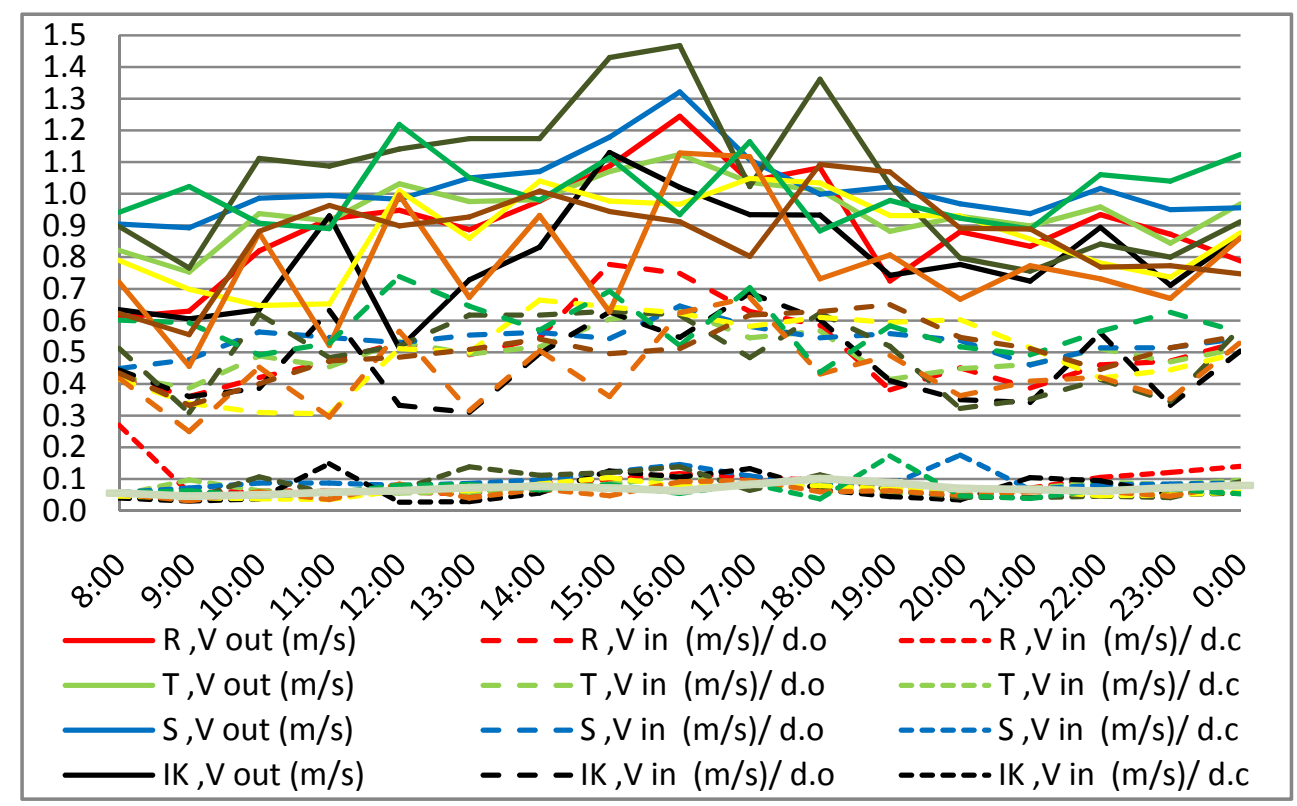

Figure 5. the behavior of indoor and outdoor air velocity at all hostels recorded in one week from 8:00 am to 12:00 am 


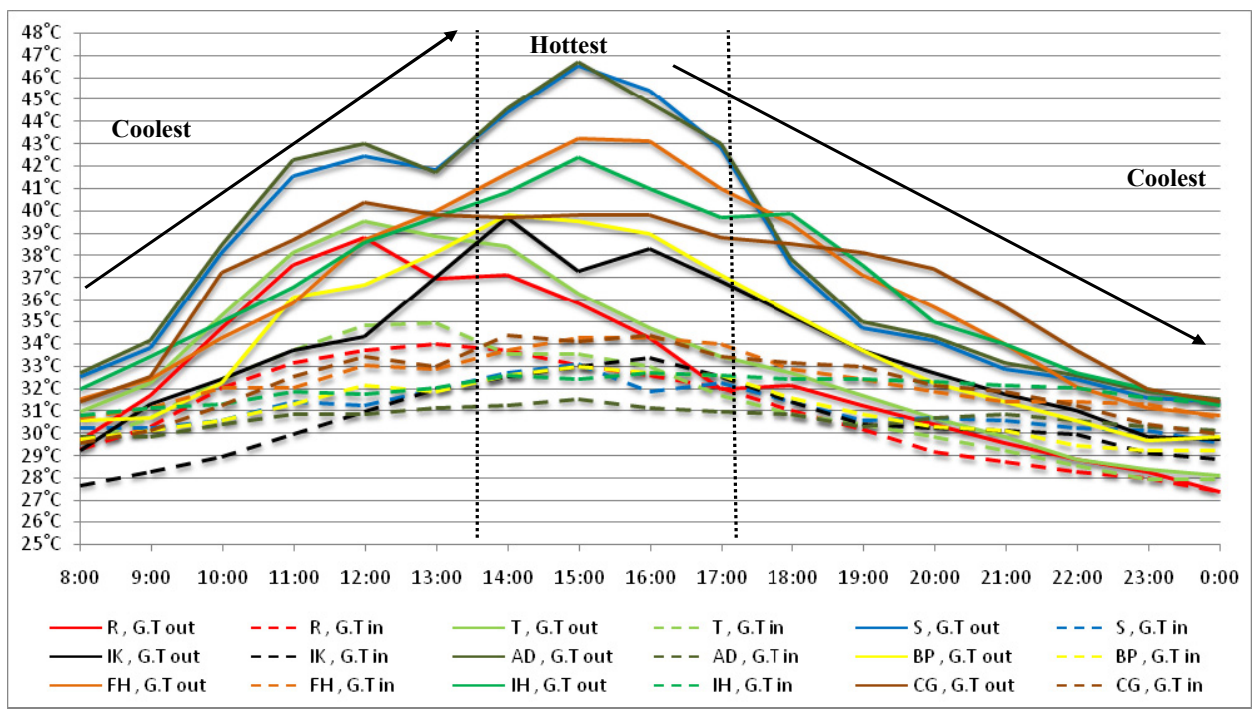

Figure 6. the behavior of indoor and outdoor globe temperature at all hostels recorded in one week from 8:00 am to $12: 00 \mathrm{am}$

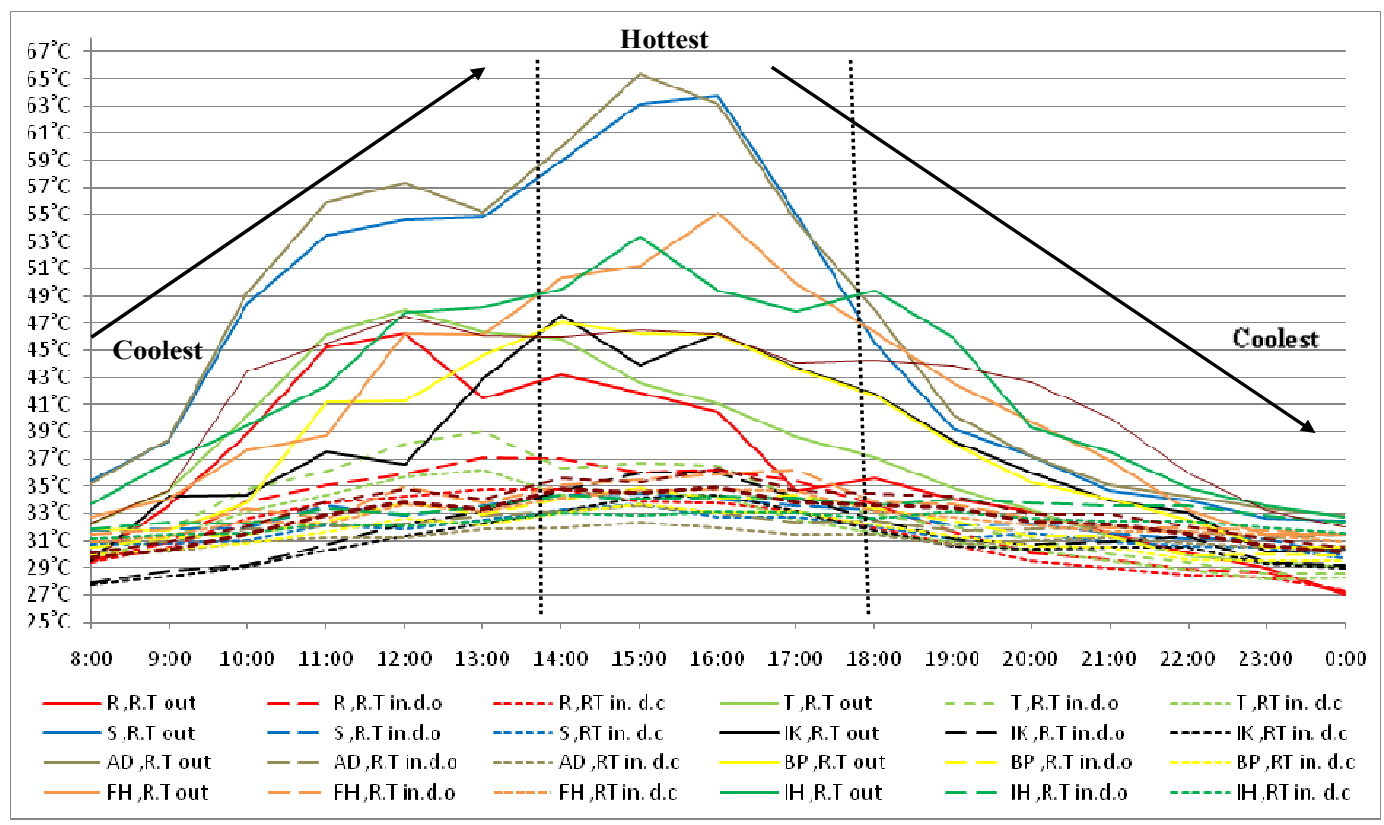

Figure 7. The behavior of indoor and outdoor radiant temperature at all hostels recorded in one week from 8:00 am to $12: 00$ am 